\title{
Continuing Value Calculation with Discounted Cash Flows Method: An Application Example for Tekart Tourism Establishment Whose Shares Are Dealt in Istanbul Stock Exchange
}

\author{
Eda Rukiye Dönbak, İsmail Ukav \\ Adıyaman University, Adıyaman, Turkey
}

\begin{abstract}
Valuation is stated as monetary value belonging to firm assets (Verginis \& Taylor, 2004). According to M. L. Rock, R. H. Rock, and Sikora (1994), valuation is the answer of the following questions: What is the maximum price that will be paid for the firm? What are the risk areas? What are the results of cash flows, profitability, and balance-sheet? Chambers $(2005$, p. 5), on the other hand, estimated a probable price that will be paid for the goods and service at a specific time. For the calculation of continuing value (CV), Verginis and Taylor (2004) used discounted cash flows (DCF) method and Önal, Karadeniz, and Kandır (2005) used economic profit method. Kırlı (2005) suggested Continuous and Constant Growing Model (Gordon Model), Value Driver Model, and Economic Profit Model. In this study, DCF which is suggested by Önal et al. (2005) and Verginis and Taylor (2004) is used for the aim of determining CV of the firm at issue. In this study, analyses are made by using the financial statement data of a tourism business whose shares are dealt in İstanbul Stock Exchange. In consequence of the calculations, $\mathrm{CV}$ of the examined firm is found to be 7,485,402 TL and firm value is found to be $15,195,366$ TL.
\end{abstract}

Keywords: firm evaluation, continuing value (CV), discounted cash flows (DCF), discount rates

\section{Introduction}

In the business world where there is intense competition, it is important to evaluate the material and nonmaterial factors of the firm as calculable and to detect the firm value in the process of rising value of the stock within the deepening financial markets (Aydın, 2012). Each method produced to guess the price and marketing value of the asset investment right should contain validity (French \& Gabrielli, 2005). Because as long as firm assets can create cash they represent a value, the firm value is tried to be determined by estimating cash flows. Firm value occurs if it makes capital investment in a way that it will provide returns above the capital cost (Copeland, Koller, \& Murrin, 1996, p. 96; Önal et al., 2005). The most common method in the calculation of the value of firms is "discounted cash flows (DCF)" method (Verginis \& Taylor, 2004).

Eda Rukiye Dönbak, Lecturer, Ph.D. student, Faculty of Tourism, Adıyaman University. Email: edonbak@adiyaman.edu.tr. İsmail Ukav, Assistant Professor, Vocational School of Kahta, Adiyaman University. 


\section{Literature Review}

\section{DCF Method}

DCF is described as the method which reduces cash flows that the firm will create in the future to present value by using the discount rate determined as of the valuation date (Aydın, 2012). Firm value is attempted to be detected by the estimation of cash flows (Ercan, Öztürk, \& Demirgüneş, 2003, p. 5; Önal et al., 2005). Firm value which is one of the variables in the equation of DCF method is formulized as follows (Önal et al., 2005):

$$
\text { Firm Value }=\sum_{t=1}^{n} \frac{(F C F F) t}{(1+W A C C) t}+\frac{(F C F F)+1 / W A C C-g}{(1+W A C C) t}
$$

where:

$t$ : Period of cash flows;

$g$ : Growth rate of cash flows after the anticipated period;

$(F C F F) t$ : Free cash flow to the firm in $t$ period in the future;

(WACC): Weighted average cost of capital.

Damodaran (2002, p. 303) and Kirlı (2005) formulized firm value as follows:

$$
V=\sum_{t=1}^{n} \frac{C F t}{(1+k) t}+\frac{\text { Continuing Value }(n)}{(1+k) n}
$$

where:

$V$ : Firm value;

$C F t$ : Cash flow in $t$ period;

$k$ : Reduction ratio;

$n$ : Estimation period of cash flows;

Continuing Value (n): Continuing value at the end of the estimated period of the company.

Process layout in DCF method (Copeland et al., 1996, p. 157):

(1) Analysis of previous data and performance;

(2) Estimation of future cash flows;

(3) Determining capital cost;

(4) Determining CV;

(5) Interpreting the results.

When the related model is wanted to be used for non-public firms, the model is tried to be applied with a comparative method by benefiting from the data (Aydin, 2012).

\section{Cash Flows}

One of the methods calculates free cash flows with reference to net profit, the other method subtracts the tax from the earnings before interest and tax $(E B I T-t)$ and calculates free cash flow with reference to this value (Önal et al., 2005). After subtracting investment expenses, for the rest amount, net changes in actives or passives are considered depending on whether they are positive or negative (Chambers, 2005, p. 225). 


\section{Weighted Average Capital Cost (WACC)}

WACC is calculated according to the weights of average costs of different sources used in financing of a firm as follows (Üreten \& Ercan, 2000, p. 61):

$$
W A C C=c e(E /(E+D+P S))+c d(D /(E+D+P S))+\operatorname{cps}(P S /(E+D+P S))
$$

where:

$c e$ : Cost of equity;

$c d$ : Cost of debts;

cps: Cost of preferred stocks;

$E /(E+D+P S)$ : The market value of equity ratio to total resources;

$D /(E+D+P S)$ : The market value of debts ratio to total resources;

$P S /(E+D+P S)$ : The market value of preferred stocks ratio to total resources.

Brealy and Myers (1988, p. 451) explained weighted average capital cost with the following formula:

$$
r^{*}=r D(1-T c) \frac{D}{V}+r E \frac{E}{V}
$$

where:

$r^{*}=$ Weighted average cost of capital;

$r D=$ Market return ratio of the firm shares;

$r E=$ Expected return ratio of the firm shares (dependent on the ratio of business risk and debt of the firm);

$T c=$ Marginal income tax ratio of the firm;

$D, E=$ Market value of equity and debt;

$V=D+E=$ Total market value of firm assets.

\section{Continuing Value (CV)}

According to CV period (Jennergren, 2008) method, CV is calculated as follows (Copeland et al., 1996, p. 287):

$$
C V=N O P L A T+1 *(1-g / R O I C) /(W A C C-g)
$$

where:

NOPLAT+1: First-year net operating profit less adjusted taxes after the expected period;

$g$ : Expected growth rate in NOPLAT value forever;

ROIC: Expected net return ratio on new invested capital.

In another method, CV can be calculated as follows (Levin \& Olsson, 2000, p. 17):

$$
C V=\frac{F C F F_{t+1}}{(W A C C-g)(1+W A C C)_{t}}
$$

where:

$F C F F$ : Free cash flow to the firm;

WACC: Weighted average cost of capital;

$t$ : Period of cash flows;

$g$ : Growth rate of cash flows after the anticipated period. 


\section{Methodology}

Accordingly, DCFs are found via the following method:

$$
D C F=\frac{A_{1}}{(1+i)^{1}}+\frac{A_{2}}{(1+i)^{2}}+\frac{A_{3}}{(1+i)^{3}}+\ldots \ldots . .+\frac{A_{n}}{(1+i)^{n}}=\sum_{t=1}^{n} \frac{A_{t}}{(1+i)^{t}}
$$

where:

$A_{t}$ : Net cash flow in $t$ th year;

$n$ : Period used in cash flows estimation;

$i$ : Discount rate.

In this study, CV of Tek-Art Construction Trade Tourism Industry and Investments Inc., which is one of the tourism businesses dealt in Istanbul Stock Exchange (BIST), is calculated according to the DCF method. In order to determine CV of the firm in question, basic financial statements between 2008-2012 years are used in the analysis. Data related to the firm are obtained from the website of Public Disclosure Platform (PDP). Four years of data of Tek-Art Construction Trade Tourism Industry and Investments Inc. taking place in both sector extent are reached and in order for the data to be cleansed from inflation, they are escalated to 2012 year. CPI annual change rates used for that purpose are given in Table $1^{1}$. Moreover, values are exchanged to ABD dollars through CBT (Central Bank of Turkey) exchange rate. The rate used for that purpose is determined as 2.03 as of the date of December 16, $2013^{2}$.

Table 1

CPI Change Rates (\%)

\begin{tabular}{llllll}
\hline Year & 2008 & 2009 & 2010 & 2011 & 2012 \\
\hline CPI (Change) & 12.72 & 1.23 & 8.52 & 11.09 & 6.09 \\
\hline
\end{tabular}

Note. Source: https://www.asmmmo.org.tr/asmmmo/content.php?content_id=40. Change rates show annual average with respect to previous December.

WACC value used while finding estimated market value of the examined tourism business is calculated with capital asset pricing model (CAPM) on an annual basis, and then it is averaged and assumed that this value will not change for the following years (Önal et al., 2005). September 2013 dated Treasury bill rate (4.40\%) of Central Bank is used as riskless interest rate in CAPM. ROIC value which is another necessary datum in calculations is assumed to be the same with WACC (Önal et al., 2005). Furthermore, some components necessary in estimation of firm value are calculated by averaging the values between the years of 2009-2012 and trends are examined. In the valuation process of analyzed tourism business for the year 2013, the following phases are applied.

\section{Results}

Financial statement values of the examined tourism business between the years of 2013-2017 are analyzed, and it is assumed that the value of the determined components will not change in the future. Under these assumptions, $\mathrm{CV}$ of the firm is calculated as follows. In the calculation of firm's $\mathrm{CV}$, for other data that must be estimated, values obtained from income tables and balance sheets in 2013-2017 of the firm are averaged.

\footnotetext{
${ }^{1} \mathrm{https} / / /$ www.asmmmo.org.tr/asmmmo/content.php?content_id=40.

${ }^{2}$ http://www.tcmb.gov.tr/kurlar/today.html.
} 
Table 2

NOPLAT Estimated Net Operating Profit Less Adjusted Taxes and Invested Capital for Expected Activities (Billion \$)

\begin{tabular}{|c|c|c|c|c|c|c|}
\hline & 2013 & 2014 & 2015 & 2016 & 2017 & Infinite \\
\hline Net sales & $7,095,600$ & $7,095,600$ & $7,095,600$ & $7,095,600$ & $7,095,600$ & $7,095,600$ \\
\hline Cost of sales except amortization & $3,520,245$ & $3,520,245$ & $3,520,245$ & $3,520,245$ & $3,520,245$ & $3,520,245$ \\
\hline Operating costs & $2,216,713$ & $2,216,713$ & $2,216,713$ & $2,216,713$ & $2,216,713$ & $2,216,713$ \\
\hline Amortization costs & 162,960 & 186,915 & 214,392 & 245,907 & 282,056 & 323,518 \\
\hline Operating profit & $1,195,682$ & $1,171,727$ & $1,144,250$ & $1,112,735$ & $1,076,586$ & $1,035,124$ \\
\hline Tax through operating profit $\% 30$ & 358,705 & 351,518 & 343,275 & 333,820 & 322,976 & 310,537 \\
\hline Net operating profit (NOPLAT) & 836,977 & 820,209 & 800,975 & 778,914 & 753,611 & 724,587 \\
\hline \multicolumn{7}{|c|}{ Invested capital for expected activities } \\
\hline & 2013 & 2014 & 2015 & 2016 & 2017 & Infinite \\
\hline $\begin{array}{l}\text { Working assets } \\
\text { (except stocks and bonds) }\end{array}$ & $15,143,145$ & $15,143,145$ & $15,143,145$ & $15,143,145$ & $15,143,145$ & $15,143,145$ \\
\hline $\begin{array}{l}\text { Short-term loans } \\
\text { (except financial liabilities) }\end{array}$ & $4,403,547$ & $4,403,547$ & $4,403,547$ & $4,403,547$ & $4,403,547$ & $4,403,547$ \\
\hline Net business capital & $10,739,598$ & $10,739,598$ & $10,739,598$ & $10,739,598$ & $10,739,598$ & $10,739,598$ \\
\hline Net tangible fixed assets & $60,719,396$ & $60,719,396$ & $60,719,396$ & $60,719,396$ & $60,719,396$ & $60,719,396$ \\
\hline Other assets - other debts & $2,754,832$ & $2,754,832$ & $2,754,832$ & $2,754,832$ & $2,754,832$ & $2,754,832$ \\
\hline Invested capital for activities & $68,704,162$ & $68,704,162$ & $68,704,162$ & $68,704,162$ & $68,704,162$ & $68,704,162$ \\
\hline
\end{tabular}

Note. Source: http://www.borsaistanbul.com/veriler/verileralt/mali-tablolar-arsiv.

CV calculation according to DCF method is as follows:

$$
\begin{gathered}
C V \text { of DCF }=[\text { NOPLAT } 2018 \times(1-(\text { Growth Rate of Sales } / \text { ROIC }))] /(\text { WACC } \\
- \text { Growth Rate of Sales }) \\
\text { CV of } D C F=[724,587 *(1-(0 / 0.0968))] /(0.0968-0)=724,587 / 0.0968=7,485,402.89
\end{gathered}
$$

Table 3

Value of Firm Activities According to DCF Method (Billion TL)

\begin{tabular}{llll}
\hline Year & Free cash flow & Present value factor & Net present value \\
\hline 2013 & 836,977 & 0.9091 & 760,895 \\
2014 & 820,209 & 0.8264 & 677,820 \\
2015 & 800,975 & 0.7513 & 601,772 \\
2016 & 778,914 & 0.6830 & 531,998 \\
2017 & 753,611 & 0.6209 & 467,917 \\
CV & $7,485,402$ & 0.6209 & $4,647,686$ \\
Value of activities previous to correction & & & $7,688,088$ \\
Midyear correction factor & & & 2.03 \\
Value of activities & & & $15,606,818$ \\
CV, Billion TL (\$) & & & $1,470,911(724,587)$ \\
NOPLAT & & & 0.0968 \\
WACC & & & 0.0968 \\
ROIC & & & 0 \\
G (growth) & & $15,195,366(7,485,402)$ \\
CV & & & \\
\hline
\end{tabular}

Notes. Source: http://www.borsaistanbul.com/veriler/verileralt/mali-tablolar-arsiv. Value of activities $=15,195,366 ;$ Stocks and bonds $=767,445 ;$ Firm value $=15,962,811$. 
In accordance with the assumptions and predictions about Tek-Art Construction Trade Tourism Industry and Investments Inc., value of activities (7,485,402 TL) and CV (7,485,402 TL) achieved as a result of the calculations made according to DCF method are detected to be the same values. When stocks and bonds are added to the value of activities, firm value is found to be $15,962,811 \mathrm{TL}$. When looked at the analysis results of Tek-Art Tourism business, value of activities (15,195,366 TL), firm value (15,962,811 TL), and CV (7,485,402 TL) are the same values according to DCF method. Moreover, the rate of firm's calculated CV to firm value is detected to be $46.89 \%$. That share of CV in the company value approaches $50 \%$ is a sign that fixed capital investments' converting to company as cash will occur in the following years.

\section{Conclusion and Implications}

The most applied method in firm evaluation studies is DCF method. "DCF method" is a commonly used and accepted method in the calculation of the firm value. While valuation is being made according to DCF method, firm value is divided into two sections: present value of cash flows in the anticipated period and present value of cash flows after the anticipated period. In this method, firm value is achieved by reducing cash flows that are expected to be obtained from the forward activities of firms to present value with a specific discount rate. However, uncertainty of cash flows that the firm will provide in the future is an important problem in the determination process of the firm value. Thus, in order to determine the firm value, it is compulsory to accept that firm lifespan is limited to a specific period. In this process, because it gets difficult to predict cash flows which occur after the period in which estimation will be made, correctly, rather than calculating cash flows which occur after the period in which estimation will be made for each year in details, the only value representing cash flows value after the projected period "Continuing Value" calculation should be resorted. As a result of the calculation, present value of cash flows after the period in which estimation will be made will be acquired and firm value will be revealed by reducing it to the valuation day. Consequently, CV has a crucial role in revealing firm value realistically. In this study, analyses are made by using the financial statement data of a tourism business whose shares are dealt in BIST; Firm value and CV are calculated. In consequence of the calculations, $\mathrm{CV}$ of the examined firm is found to be 7,485,402 TL and firm value is found to be $15,195,366$ TL. In conclusion, it is understood that CV of the examined firm makes a significant share of $46.89 \%$ of firm value. This situation reveals how important CV is in firm evaluation.

\section{References}

Aydin, Y. (2012). Firm evaluation methods. Kirklareli Üniversity I.I.B.F. Journal, 1(1).

Brealey, R. A., \& Myers, S. C. (1988). Principles of corporate finance. McGraw-Hill Publishing Company.

Chambers, N. (2005). Firm evaluation (1st ed.). İstanbul: Avc1ol Press.

Copeland, T. E., Koller, T., \& Murrin, J. (1996). Valuation: Measuring and managing the value of companies. McKinsey \& Company, Inc..

Damodaran, A. (2002). Investment valuation: Tools and techniques for determining the value of any asset (2nd ed.). New York, NY: John Wiley \& Sons, Inc..

Ercan, M. K., Öztürk, B., \& Demirgüneş, K. (2003). Value-based management and intellectual capital based on value. Ankara: Gazi Bookstore.

French, N., \& Gabrielli, L. (2005). Discounted cash flow: Accounting for uncertainty. Journal of Property Investment \& Finance, 23(1), 75-89.

Jennergren, P. (2008). Continuing value in firm valuation by the discounted cash flow model. European Journal of Operational Research, 185(3), 1548-1563. 
Kırlı, M. (2005). Determining continuing value as an input of discounted cash flows method in firm evaluation. Celal Bayar Üniversity İI. B.F. Management and Economy Journal, 12(2), 157-169.

Levin, J., \& Olsson, P. (2000). Terminal value techniques in equity valuation - Implications of the steady state assumption. SSE/EFI Working Paper Series in Business Administration No. 2000:7.

Önal, Y. B., Karadeniz, E., \& Kandir, S. Y. (2005). Calculating continuing value: An application on a tourism business quoted on İstanbul Stock Exchange. Çukurova Üniversity Institute of Social Sciences Journal, 14(2), 369-390.

Rock, M. L., Rock, R. H., \& Sikora, M. (1994). The mergers and acquisitions handbook. New York, NY: McGraw-Hill.

Üreten, A., \& Ercan, M. K. (2000). Firm value detection and management. Ankara: Gazi Bookstore.

Verginis, C. S., \& Taylor, J. S. (2004). Stakeholders' perceptions of the DCF method in hotel valuations. Journal of Property Management, 22(5), 358-376. 